\title{
Automatic Dehydration Level Detection Devices
}

\author{
(Equipped With pH Measurements and Calculation Of Body Fluid Requirements)
}

\author{
Diana Dwi Damayanti ${ }^{1}$, Her Gumiwang Ariswati ${ }^{1}$, I Dewa Gede Wisana ${ }^{1}$, Hendra Winarno ${ }^{2}$ \\ ${ }^{1}$ Electromedical Engineering Department of Politeknik Kesehatan Kementerian Kesehatan Surabaya \\ Jl. Pucang Jajar Timur No. 10, Surabaya (60282), Indonesia \\ ${ }^{2}$ Universitas Muhammadiyah Gresik \\ Jl. Sumatera No.101, Gn. Malang, Randuagung, Kec. Kebomas, Kabupaten Gresik, 61121, Indonesia \\ E-mail: dianadamayanti275@gmail.com
}

\begin{tabular}{|c|c|}
\hline Article Info & Abstract \\
\hline $\begin{array}{l}\text { History Articles: } \\
\text { Receive Mei 15, } 2020 \\
\text { Revised August 10, } 2020 \\
\text { Received August 30, } 2020\end{array}$ & $\begin{array}{l}\text { Dehydration is a condition that occurs when the loss of body fluids exceeds the amount entered in } \\
\text { the body so that it can disrupt the balance of minerals in body fluids. Most people do not feel thirsty } \\
\text { until finally, they experience a period of severe dehydration, which can cause physical, cognitive, } \\
\text { fatigue; if not corrected immediately can cause death. The purpose of this study is to design a } \\
\text { dehydration and urine pH detection devices automatically. The contribution of this study is that this } \\
\text { device is equipped with urine pH measurement and automatic body fluid calculation. This device is } \\
\text { able to detect urine color levels, read urine pH values, and provide information on body fluids needed }\end{array}$ \\
\hline $\begin{array}{l}\text { Keywords: } \\
\text { Dehydration } \\
\text { TCS34725 } \\
\text { pH meter } \\
\text { Graphic LCD }\end{array}$ & $\begin{array}{l}\text { to treat the patient's condition when detected. The sensors used in this device are color sensor } \\
\text { TCS34725, pH meter sensor module SKU-016 and DS18B20 temperature sensor, the calculation of the } \\
\text { amount of fluid that must be entered automatically from the patient's body weight input. The } \\
\text { programming uses Arduino Nano as the main controller with a } 128 \times 64 \text { graphic LCD. From the testing } \\
\text { that has been done, it is known that the percentage error in the module is } 3.5 \% \text {, which means that it is } \\
\text { still in the tolerance value because the tolerance limit is } 5 \% \text {, for the sensitivity test results get a value } \\
\text { of } 60 \% \text { and specificity of } 70 \% \text {. Thus, it shows that the device is feasible and can be implemented as a } \\
\text { dehydration detection device that is carried out independently at home. }\end{array}$ \\
\hline
\end{tabular}

The corresponding author:

Her Gumiwang Ariswati

Electromedical Engineering Department

Politeknik Kesehatan Kementerian Kesehatan Surabaya

Jl. Pucang Jajar Timur No. 10, Surabaya (60282), Indonesia

E-mail: ariswatihergumiwang@gmail.com
This is open access articles and licensed under Creative Commons Attribution-Non-Commercial $4.0 \quad$ License International,

\section{INTRODUCTION}

Health monitoring can be done independently, one of which is biochemical tests which are generally often carried out by many people. One of the biochemical tests is a urine examination, which is done independently at home. Urinalysis is recommended to be part of the initial examination of all patients because it is cheap, feasible, and provides productive results[1]. Urine examination in patients provides very extensive information based on existing parameters and can indicate problems in the body. Information that can be identified includes urine color, urine sediment, urine $\mathrm{pH}$, protein, glucose, nitrite, red blood cells, and white blood cells, bilirubin [2]. In the urine color and pH check, the test is usually done manually using a color strip that uses strip paper as a comparison. The results are often obtained by semi-quantitative analysis, where only people with expertise can read the results of the manual test. In the context of health, home-monitoring is generally done by reading manually reading error-prone. Also, parents or people who are color blind are likely to face difficulties in conducting rapid visual analysis, which can lead to incorrect results. Therefore biochemical tests are automatic and can provide easy information that is very much needed in such cases. Biochemical tests through urine can detect kidney damage, from the results of these tests immediately carried out further tests on the patient, to follow up on the treatment of kidney damage[3][4]. Dehydration or loss of body fluids is often experienced unconsciously. Most people do not feel thirsty until finally, they experience a period of severe dehydration[5][6][7]. Water is needed in the body for metabolic processes, body temperature regulation, joint lubrication, distribution of nutrients, and so on[8][9]. Acute dehydration can cause physical and cognitive disorders, heatstroke and fatigue, and if severe and uncorrected, even death[10][11]. Apart from infants and people with special medical conditions, athletes, military personnel, workers, and older adults are at particular risk of dehydration due to their physical activity, environmental exposure, and the challenges of maintaining fluid homeostasis[12][13]. The earliest detection of dehydration is the color of urine, which is often unknown is the calculation of fluids that must enter the body when dehydration is detected, therefore the need for an 
automatic dehydration detector and is equipped with an automatic calculation of the amount of fluid entering the body. Also, the $\mathrm{pH}$ level (Power of Hydrogen) plays an important role in the maintenance of human metabolic activity. The kidneys have a role in regulating the concentration of hydrogen ions in body fluids to prevent acidosis or a way to excrete acid or alkaline urine[2]. In the body can describe accurately the concentration of hydrogen ions in it. Excessive acidity of urine may be a sign of diabetes, systemic acidosis, dehydration, etc. Urinary excessive alkalinity may be a sign of bacteriuria or kidney failure[14]. The reverse, the $\mathrm{pH}$ of the urine becomes alkaline can be due to urinary tract infections, pyloric, chronic kidney failure, certain drug therapies. Examination of urine color and urine $\mathrm{pH}$ does not have to wait to the clinical laboratory, and the examination can be done at home as an early detection if dehydration is detected so that it can be handled directly by entering fluids in the body as needed by the body and can be checked again until it is classified as normal urine. Likewise, with the $\mathrm{pH}$ value in the urine if the reading of the $\mathrm{pH}$ value is not normal then immediately carried out further examination and treatment, because it indicates a problem in the kidney[15][16].

A similar study was conducted by Rint Zata in 2017 with the title Dehydration Detection System Based on color and ammonia levels in the urine based on TCS3200 and MQ135 sensors with the Naïve Bayes method[17]. From this device, the level of dehydration and the level of ammonia in the urine were detected. However, the device has not been equipped with body fluid needs. Subsequent research was carried out by Ika Shofiyah Naharin in 2018, and she developed an automatic detection of dehydration levels based on the color of urine supplemented with the number of fluid needs. The device uses the TCS3200 color sensor to detect the color of urine and the amount of fluid needed for the body. However, there has been no development of measurements for other urine components, the TCS3200 sensor reading error value is still relatively high, and the device is not yet portable, so there are limitations in placement when making measurements. Further research was carried out by Alexander et al. in 2018, and they propose a urine dehydration system based on urine color [18]. The device uses the same sensor as what the author will develop, namely the TCS34725 color sensor. In his research, he gave conclusions and hopes for future research to establish the system to modify other parameters such as $\mathrm{pH}$, specific gravity, glucose, etc. This system can be implemented in a home system[19].

Based on the weaknesses and limitations that have been mentioned in previous researchers, among others: 1) There is no other parameter to detect dehydration other than the color of urine 2) not portable; 3) the type of sensor used is less than the maximum in detection. Against this background, the authors intend to research the title Detection of Dehydration and Urine $\mathrm{pH}$ Automatically. It was using a sensor that is different from before using the TCS34725 sensor and adding another parameter in the examination of the urine component, namely the measurement of the $\mathrm{pH}$ value. It is hoped that this device can help to monitor health at home through early detection of dehydration as well as knowing the needs of fluids in the body and knowing the $\mathrm{pH}$ of urine to determine whether there are metabolic problems, especially in the kidneys and the devices are made using different sensors from previous studies, and the device is made automatically and portable to make it easier to use.

This Article is composed of: Chapter 1 Introduction, Chapter 2 Material and Methods, Chapter 3 Result, Chapter 4 Discussion, Chapter 5 Conclusion, and Chapter 6 Reference.

\section{MATERIALS AND METHODS}

\section{A. Experimental Setup}

This study conducted using eight samples to detect and measure. Samples were obtained from liquids whose color approached the color scale urine hydration chart.

\section{B. Materials and Device}

In this study, we used a TCS34725 color sensor (TCS34725FN, TCS34725, Headquarter sams AG Tobelbader Strasse 308141 Premstaetten Austria, Europe) (Fig. 1), pH meter module sensor SKU-016 (PH-4502C, DIY MORE \& BNC Electrode $\mathrm{pH}$ probe, China) (Fig. 2), temperature sensor DS17B20 (waterproof, Maxim Integrated Products, China), buffer $\mathrm{pH} 4.01$ and aqua dest for calibration of the $\mathrm{pH}$ meter electrode, and some solutions according to the urine hydration color scale. Components used in this study is a microcontroller Arduino Nano (programming by software Arduino 1.8.2) and 128x64 LCD graphic as the display.

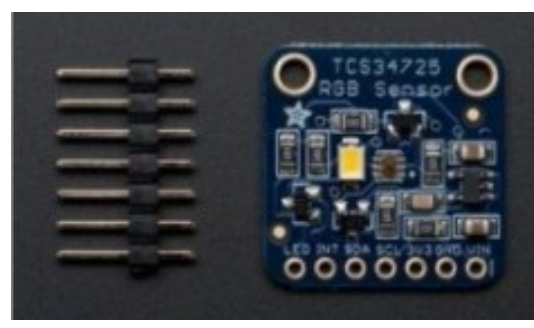

Fig. 1. TCS34725 Color Sensor[20]

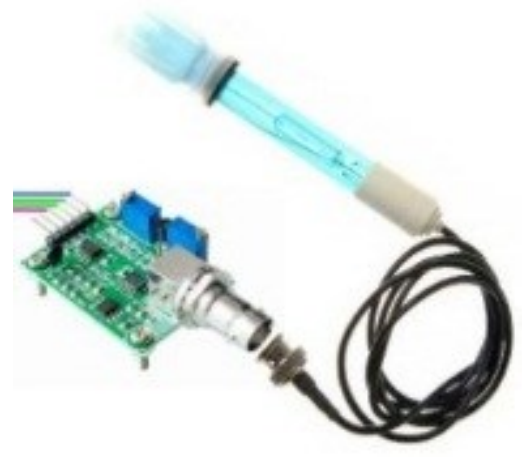

Fig. 2. pH Meter Module Sensor SKU-016

\section{Experiment Protocol}

In order to experiment, provide a liquid to be detected in accordance with the color scale urine hydration chart (Fig. 3). 


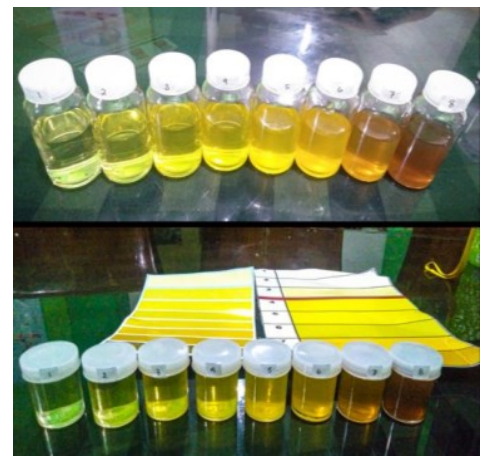

Fig. 3. Liquid Accordance With The Color Scale Urine Hydration Chart

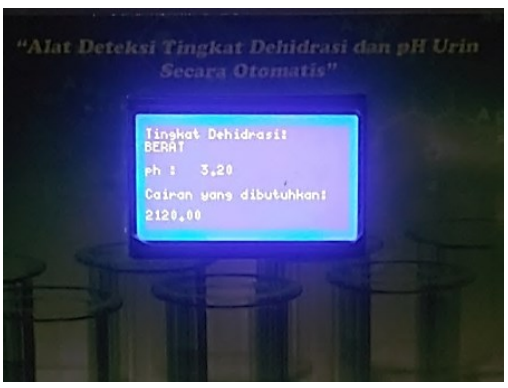

Fig. 4. Final Information

Color detection using the TCS34725 color sensor, the board is blue as in (Fig. 1), after which the liquid is measured $\mathrm{pH}$ using the pH meter module sensor SKU-016 as in (Fig. 2) with calibration step using buffer 4.01. then the electrodes are cleaned utilizing a tissue carefully until completely clean and dry after that dipped in aqua liquid and did the same thing. Then dip pH meter electrode in the liquid to be measured after the value appears on display. Select the weight input menu, enter digits of the when conditions are taken for sampling. Final information will come out on the screen from the detected results as in (Fig. 4) shows the level of dehydration, $\mathrm{pH}$, and fluids that the body needs to overcome this.

\section{Diagram Block}

The input was obtained from the sample. First, the sample color check is performed, the color of the sample is detected by the TCS34725 color sensor, and the $\operatorname{ADC}(\mathrm{R}, \mathrm{G}, \mathrm{B})$ data is generated and processed by Arduino program. Second, it takes the $\mathrm{pH}$ of the sample. Before it carries the $\mathrm{pH}$ check out, the sample is dipped by a $\mathrm{pH}$ meter electrode and then processed by the $\mathrm{pH}$ meter sensor module to produce a voltage output, which is then treated with a buffer amplifier circuit. In the examination of $\mathrm{pH}$ temperature also affects the reading results; therefore, the sample is also measured by using a DS17B20 waterproof sensor. After that, the measurement results of the $\mathrm{pH}$, temperature, and color of the sample are displayed on the graphic LCD.

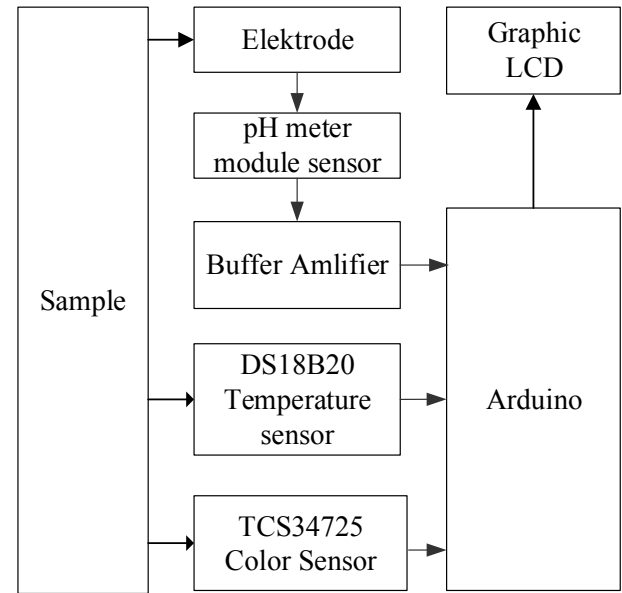

Fig. 5. A Block Diagram System

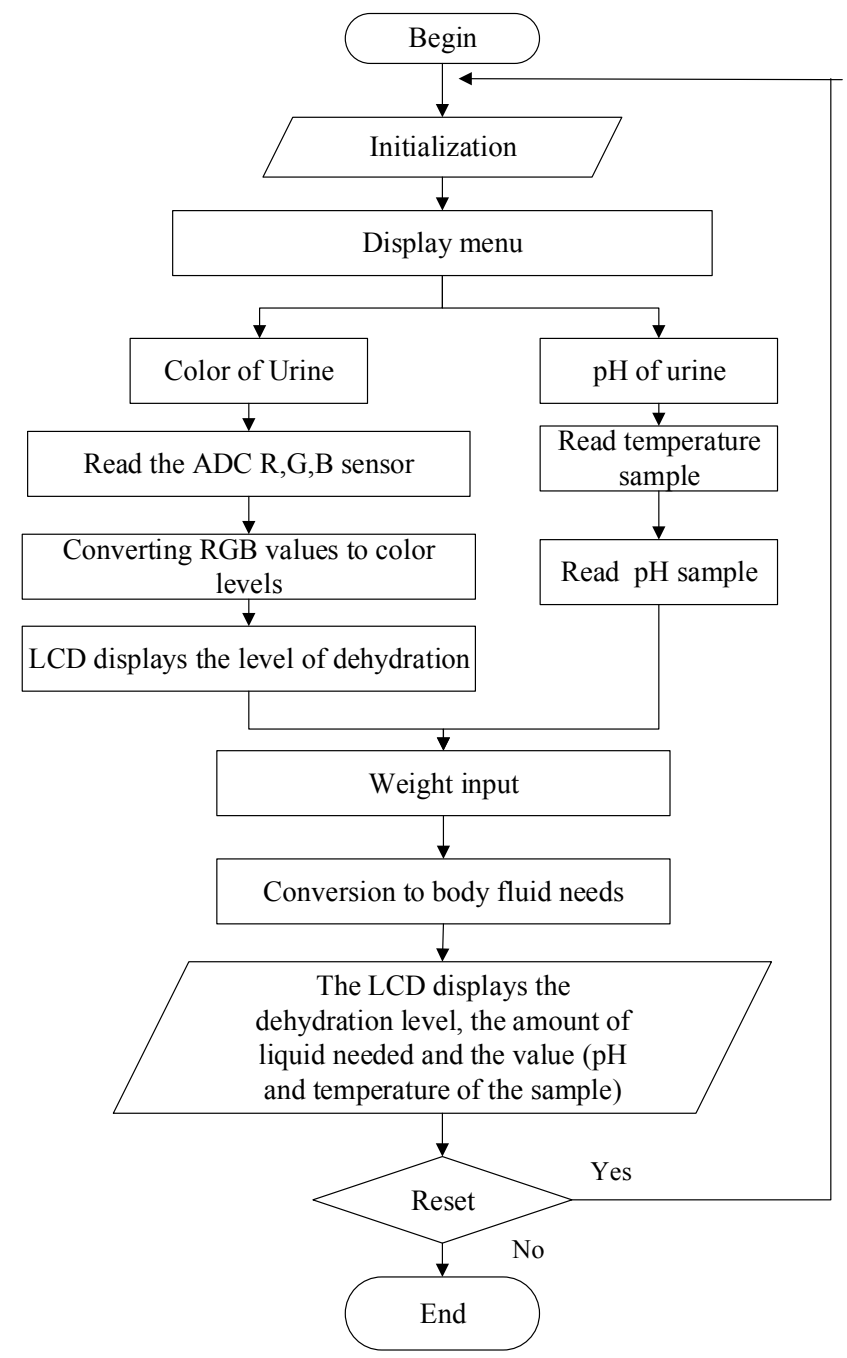

Fig. 6. The Flowchart Program Arduino 


\section{E. The Flowchart}

The flowchart of the proposed method is shown in (Fig. 6). The program starts from the LCD initialization with three menu displays, namely color detection, $\mathrm{pH}$ and temperature measurement, the weight input. After measuring in the first and second menus and then selecting the 3rd menu for weight input, then press enter, then the general information will appear on the LCD screen. There is also a reset button to return to the initial LCD initialization program.

\section{F. Circuit}

\section{1) $\mathrm{pH}$ Meter Module Sensor}

The $\mathrm{pH}$ meter input module SKU-016 is derived from the electrode dipped in the sample and the sensor output pin is connected to the buffer amplifier circuit.

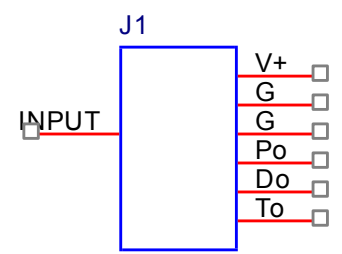

MODUL PH METER

Fig. 7. $\mathrm{pH}$ Meter Module Sensor

\section{2) Buffer Amplifier}

The input circuit is derived from the $\mathrm{pH}$ meter output of the sensor module, this circuit comprises 2 circuits namely a buffer circuit that functions so that the input voltage and output voltage are the same and the amplifier circuit to amplify the voltage which then outputs the incoming circuit at the Arduino A0 pin.

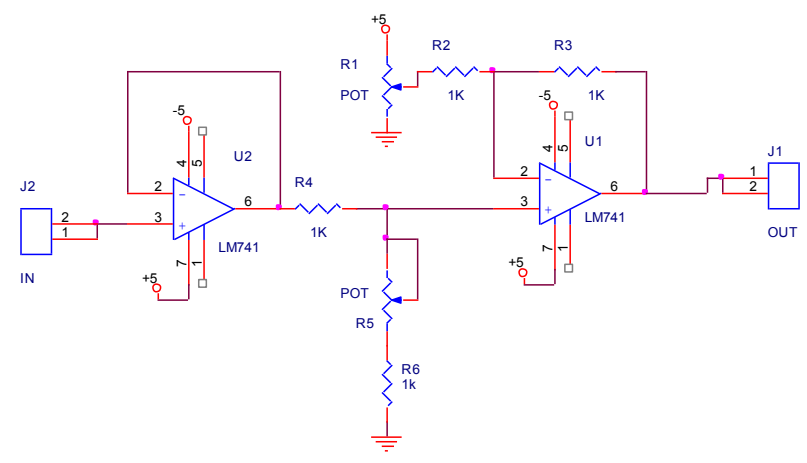

Fig. 8. Instrumentation Ampifier

\section{3) TCS34725 Color Sensor}

It connects the tcs34725 sensor to the VCC, GND, SDA and SCL pins on the Arduino pin.

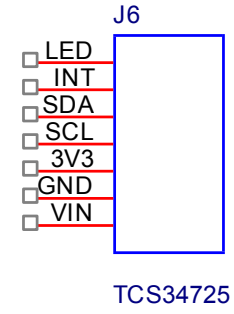

Fig. 9. TCS34725 Color Sensor

\section{4) DS18B20 Temperature Sensor Connection}

It connects the DS18B20 sensor to the pull-up circuit and then connected to the Arduino D12 pin.

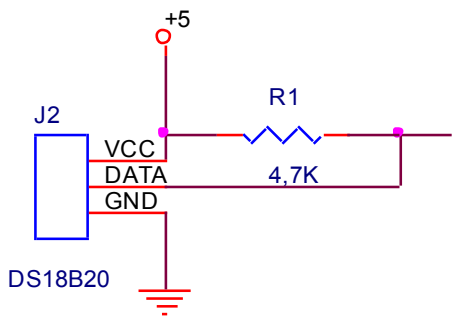

Fig. 10. DS18B20 Temperature Sensor

\section{RESULT}

In the research carried out, it carried tests out using 8 sample colors that resembled eight levels of color scale urine hydration chart. (Fig. 11).

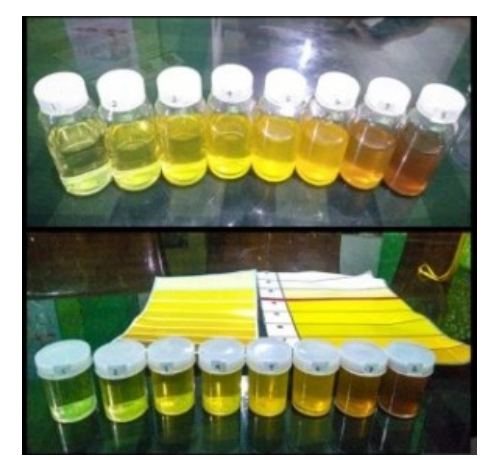

Fig. 11. Fluid Samples Used For Measurement

\section{A. Device Design}

We can see the design of the instrument (Fig. 12). There is an exact sample that has the surface of the box in which there is a tube to insert the sample at the time of color detection. There are push buttons for setting and selecting menus. There are two connectors on the right side in the picture, which are connected to the $\mathrm{pH}$ meter electrode and temperature sensor. 


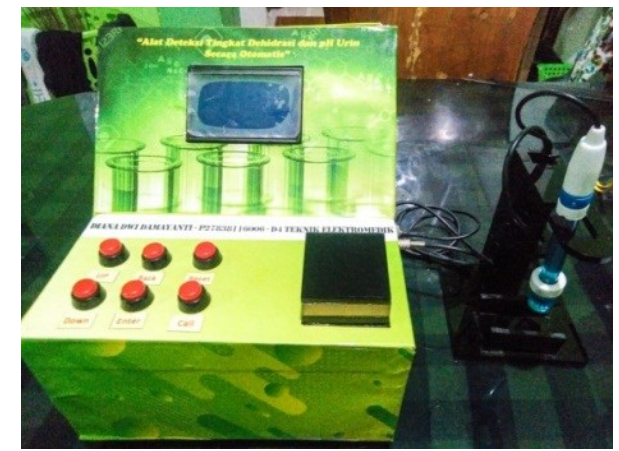

Fig. 12. Automatic Dehydration and pH Urine Level Detection Device

\section{B. The Results of Program Arduino}

In the Arduino program is divided into 6, namely the color level reading program, the $\mathrm{pH}$ reading program, the temperature reading program, the weight input program, and the liquid calculation program.

\section{Pseudocode 1. The Program is to Read Color By Sensor} TCS34725

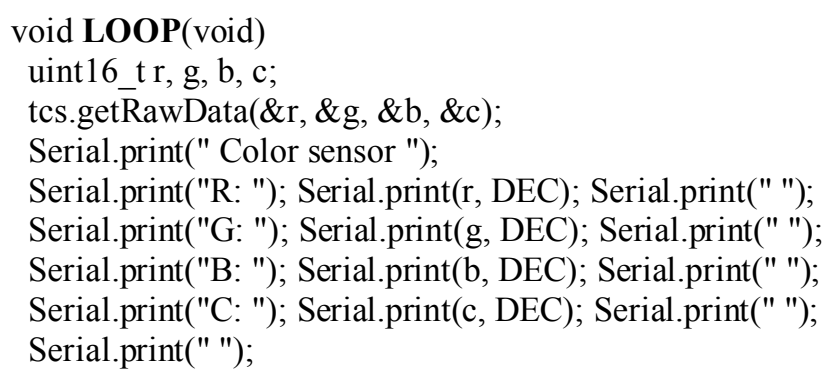

This program is used for the color reading of the sample, which will later be read the ADC value of its $R, G, B$.

\section{Pseudocode 2. The Program is to Convert RGB Digital Data to Color Levels}

Make 8 program for 8 color scale of urin hydration, for example as follows :

IF $(($ reda $>=1.12 \&$ reda $<=1.13) \& \&($ greena $>=1.07 \&$ greena $<=1.08) \& \&$ (bluea $>=0.79 \&$ bluea $<=0.81)$ ) THEN

u8g.drawStr(37, 40, "Normal");

condition $=1$;

\section{ENDIF}

ELSE IF ((reda $>=1.15 \&$ reda $<=1.19) \& \&$ (greena $>=1.04$ $\&$ greena $<=1.05) \& \&($ bluea $>=0.75 \&$ bluea $<=0.80)$ ) THEN u8g.drawStr(20, 40, "Dehydrated ");

condition $=4$;

ENDIF
ELSE IF $(($ reda $>=1.14 \&$ reda $<=1.19) \& \&($ greena $>=0.98$ $\&$ greena $<=0.99$ ) \&\& (bluea $>=0.82 \&$ bluea $<=0.88)$ ) THEN

u8g.drawStr(20, 40, "Severe Dehydration");

condition $=8$;

\section{ENDIF}

ELSE

u8g.drawStr(20, 40, "..........");

ENDELSE

This program is used to convert the reading data in the form of $\mathrm{R}, \mathrm{G}, \mathrm{B}$ values to a color level. This program is used for setting tools to achieve correct and accurate readings.

\section{Pseudocode 3. The program is to Read pH Value}

\section{DEFINE}

int $\mathrm{pHvalue}=$ analogRead(phSensorPin $)$;

Voltage $\mathrm{Ph}=5 / 1024.0 *$ pHvalue;

phadc $=$ pHvalue;

phteg $=($ VoltagePh $)$

Pseudocode 4. The Program is to Calibration 1 Point

DEFINE

$\mathrm{pH}=(-0.0184 * \mathrm{pHvalue})+18.481$;

When the sensor was performing calibration, the media was set using a $\mathrm{pH}$ powder of 4.01. The formula added to the program is made using Excel to adjust the value when the setting is done.

Pseudocode 5. The Program is to Readings From The Temperature Sensor

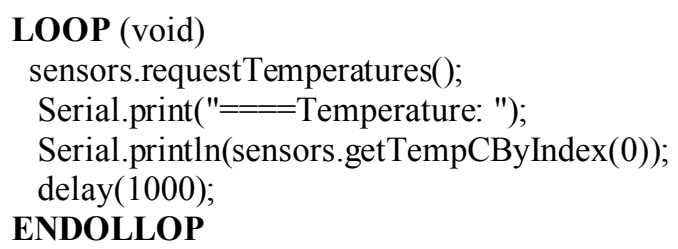

This program is used for reading the temperature value at the time of $\mathrm{pH}$ measurement because the temperature value affects the $\mathrm{pH}$ value, therefore, a temperature sensor must be added when measuring the $\mathrm{pH}$ of the sample. 
Pseudocode 6. The Program is to Calculation of Fluid Requirements

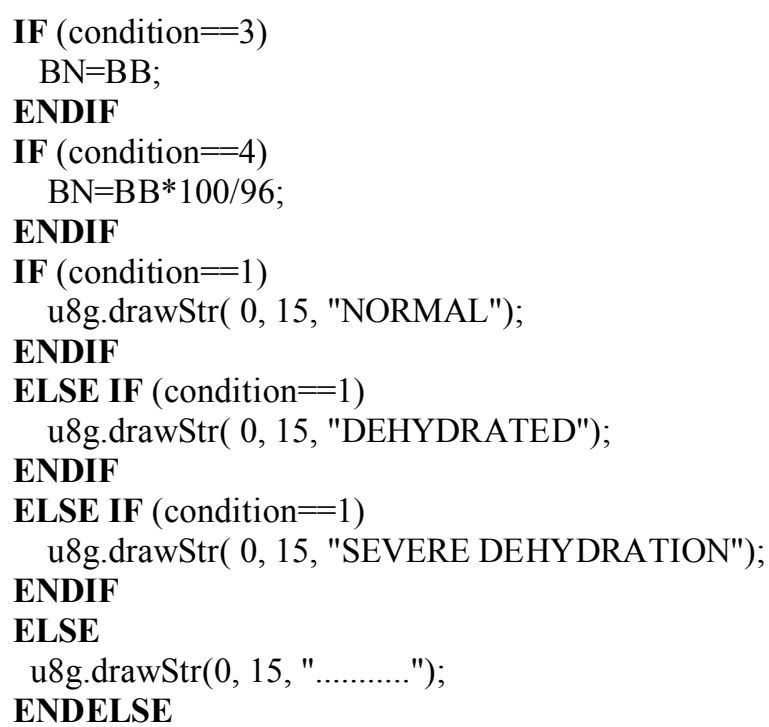

This program is used to automatically calculate the body's fluid requirements using a formula and input derived from the patient's body weight

\section{The Results of The Output TCS34725}

The output of the sensor detection is displayed on the graph (Fig. 13) for easy reading.

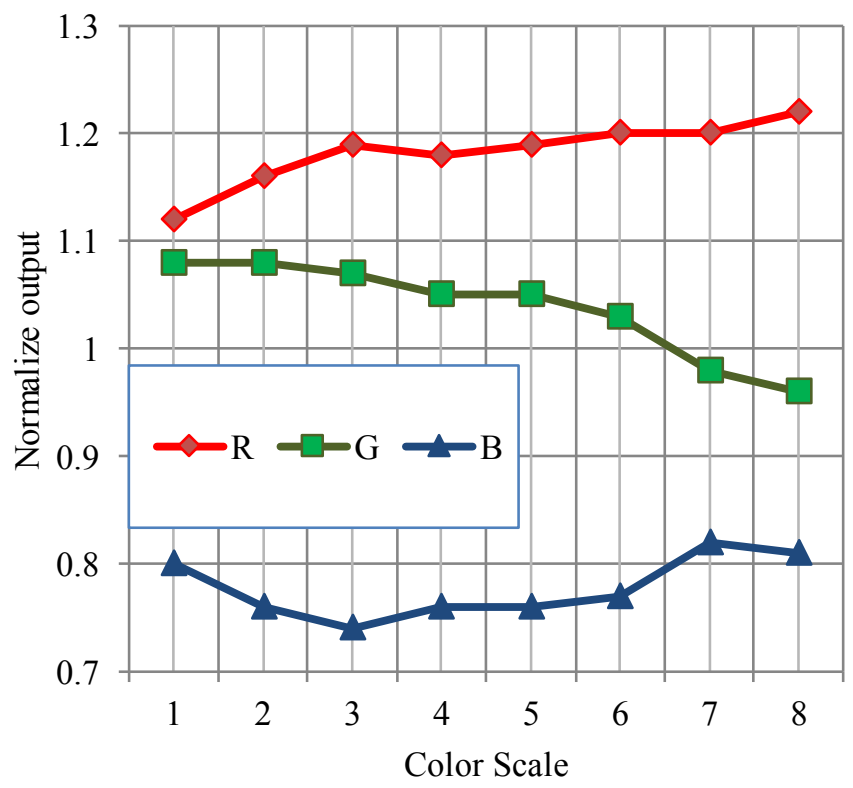

Fig. 13. Graphic RGB Value of Output TCS34725

\begin{tabular}{|c|c|c|c|c|c|c|}
\hline $\begin{array}{l}\text { Sam } \\
\text { ple }\end{array}$ & $\begin{array}{c}\text { Module } \\
\text { TCS3472 } \\
5\end{array}$ & $\begin{array}{l}\mathrm{pH} \\
\text { meter }\end{array}$ & $\begin{array}{l}\text { Weight } \\
\text { gain } \\
\text { when } \\
\text { dehydr } \\
\text { ated }\end{array}$ & $\begin{array}{c}\text { Weight } \\
\text { gain } \\
\text { when } \\
\text { normal } \\
\text { conditio } \\
\text { n } \\
\end{array}$ & Status & $\begin{array}{l}\text { Fluid } \\
\text { need } \\
(\mathrm{mL} / \\
\text { days })\end{array}$ \\
\hline 1 & $\begin{array}{l}\mathrm{R}=1.12 \\
\mathrm{G}=1.08 \\
\mathrm{~B}=0.81\end{array}$ & 2.80 & 60 & 62.5 & Normal & $\begin{array}{c}2300 \\
\mathrm{ml}\end{array}$ \\
\hline 2 & $\begin{array}{l}\mathrm{R}=1.16 \\
\mathrm{G}=1.07 \\
\mathrm{~B}=0.77\end{array}$ & 2.69 & 54 & 54 & Normal & 2180 \\
\hline 3 & $\begin{array}{l}\mathrm{R}=1.18 \\
\mathrm{G}=1.06 \\
\mathrm{~B}=0.76\end{array}$ & 2.97 & 46 & 46 & Normal & 2020 \\
\hline 4 & $\begin{array}{l}\mathrm{R}=1.18 \\
\mathrm{G}=1.05 \\
\mathrm{~B}=0.76\end{array}$ & 2.73 & 47 & 50 & Fair & 2060 \\
\hline 5 & $\begin{array}{l}\mathrm{R}=1.13 \\
\mathrm{G}=1.04 \\
\mathrm{~B}=0.83\end{array}$ & 2.65 & 48 & 50 & $\begin{array}{l}\text { Dehydr } \\
\text { ated }\end{array}$ & 2100 \\
\hline 6 & $\begin{array}{l}\mathrm{R}=1.16 \\
\mathrm{G}=0.99 \\
\mathrm{~B}=0.85\end{array}$ & 2.67 & 56 & 56 & $\begin{array}{c}\text { Dehydr } \\
\text { ated }\end{array}$ & 2264 \\
\hline 7 & $\begin{array}{l}\mathrm{R}=1.15 \\
\mathrm{G}=0.99 \\
\mathrm{~B}=0.87\end{array}$ & 2.65 & 45 & 45 & $\begin{array}{c}\text { Very } \\
\text { dehydr } \\
\text { ated }\end{array}$ & 2054 \\
\hline 8 & $\begin{array}{l}\mathrm{R}=1.15 \\
\mathrm{G}=0.99 \\
\mathrm{~B}=0.87\end{array}$ & 3.20 & 48 & 50 & $\begin{array}{c}\text { Severe } \\
\text { dehydr } \\
\text { ated }\end{array}$ & 2120 \\
\hline
\end{tabular}

Table I. explains about overall measurements when the device works in sequence according to the system made.

D. Measurement Error

TABle II. CALCUlation OF PH SENSOR ERror VAlues

\begin{tabular}{ccccc}
\hline Sample & $\begin{array}{c}\mathrm{pH} \\
\text { (Module) }\end{array}$ & $\begin{array}{c}\mathrm{pH} \\
\text { (comparison } \\
\text { device) }\end{array}$ & $\begin{array}{c}\text { Deviation } \\
\text { (comparison } \\
\text { device- } \\
\text { Module/ } \\
\text { comparison } \\
\text { device) }\end{array}$ & \% error \\
\hline 1 & 2.8 & 2.46 & 0.13821 & 13.8211 \\
\hline 2 & 2.69 & 2.16 & 0.24537 & 24.537 \\
\hline 3 & 2.97 & 3.26 & 0.088957 & 8.895706 \\
\hline 4 & 2.73 & 2.86 & 0.045455 & 4.545455 \\
\hline 5 & 2.65 & 2.46 & 0.07724 & 7.72358 \\
\hline 6 & 2.67 & 2,87 & 0.069686 & 6.968641 \\
\hline 7 & 2.69 & 2.52 & 0.06746 & 6.74603 \\
\hline 8 & 3.2 & 3.01 & 0.06312 & 6.31229 \\
\hline & & & Average $1:$ & 4.84128 \\
\hline
\end{tabular}


Table II. explains the calculation of the error $\mathrm{pH}$ value in the module compared to the comparison device.

TABLE III. CALCUlation OF TEMPERATURE SENSOR ERror VAluES

\begin{tabular}{ccccc}
\hline Sample & $\begin{array}{c}\text { Temperature } \\
\text { of the } \\
\text { sample } \\
\text { (module) }\end{array}$ & $\begin{array}{c}\text { Temperature } \\
\text { of the } \\
\text { sample } \\
\text { (comparison } \\
\text { device) }\end{array}$ & $\begin{array}{c}\text { Deviation } \\
\mid \text { (comparison } \\
\text { device- } \\
\text { Module/ } \\
\text { comparison } \\
\text { device) }\end{array}$ & \% error \\
\hline 1 & 29 & 28.6 & 0.01399 & 1.3986 \\
\hline 2 & 29.38 & 28.5 & 0.03088 & 3.08772 \\
\hline 3 & 29 & 28.7 & 0.01045 & 1.0453 \\
\hline 4 & 29.5 & 28.6 & 0.03147 & 3.14685 \\
\hline 5 & 29.63 & 28.7 & 0.0324 & 3.24042 \\
\hline 6 & 29.75 & 28.8 & 0.03299 & 3.29861 \\
\hline 7 & 29.31 & 29.3 & 0.00034 & 0.03413 \\
\hline 8 & 29.94 & 28.9 & 0.03599 & 3.59862 \\
\hline & & & Average $2:$ & 2.35628 \\
\hline
\end{tabular}

Table III. explains the calculation of the temperature value in the module compared to the comparison device.

Overall error value

$$
\begin{gathered}
\text { Error } \quad=\frac{\mathrm{A} 1+\mathrm{A} 2}{16} \\
=\frac{4.84128+2.35628}{2}=3.59878 \% \\
\text { IV. DISCUSSION }
\end{gathered}
$$

\section{DISCUSSION}

Previous research in 2017 which is conducted by Rint Zata [17], there was a development of parameters that detect through the color of urine gas and ammonia gas, and other studies mostly using TCS3200 color type sensors, for the current development using TCS34725 color sensors whose quality is better because there are IR block filters. Further research was carried out by Alexander et al. in 2018 [18].The device uses the same sensor, namely the TCS34725 color sensor. Still, the dehydration detection parameter is only through the color of urine and suggests that there be additional development of other parameters. Now, this study is done by adding a different parameter, namely urine $\mathrm{pH}$, because $\mathrm{pH}$ affects the dehydration condition, and I also add that the calculation of body fluids is needed automatically. In Table II. and Table III. that this device is suitable for use as detection of dehydration at home as early detection of dehydration status in the body.

\section{CONCLUSION}

This study shows the development of a community movement to check urine itself by making a dehydration level detection device that is equipped with urine $\mathrm{pH}$ measurement and automatic body fluid calculation. This study uses Arduino programming to create the desired system. Program processing uses Arduino Uno and is displayed on a 128x64 graphic LCD. This study has an error value of $3.5 \% \%$, which means that it is still in the tolerance value because the tolerance limit is $5 \%$, a sensitivity of $60 \%$ and a specificity of $70 \%$. That it shows that the device to be feasible and can be implemented as a dehydration detection device that is carried out independently at home. In the future, I expect it, that development can be carried out for the addition of other urine component detection parameters.

\section{REFERENCE}

[1] S. Dey, T. Saha, and U. Narendrakumar, "Analysis of Urine as Indicators of Specific Body Conditions," 2017.

[2] J. M. Sands and H. E. Layton, "The Physiology of Urinary Concentration : An Update,” YSNEP, vol. 29, no. 3, pp. 178-195, 2009.

[3] M. Velikova, R. L. Smeets, J. Terwisscha, P. J. F. Lucas, and M. Spaanderman, "Smartphone-based analysis of biochemical tests for health monitoring support at home," vol. 1, pp. 92-97, 2014.

[4] R. Loesnihari, "Peran analisa urin pada penanganan penyakit ginjal dan traktus urinarius," vol. 45, no. 3, pp. 167-176, 2012.

[5] I. M. Krecar, M. Kolega, and S. F. Kunac, "The Effects of Drinking Water on Attention," Procedia - Soc. Behav. Sci., vol. 159, pp. 577-583, 2014.

[6] Y. Women et al., "Mild Dehydration Affects Mood in Healthy," $J$. Nutr., vol. 142, no. 2, pp. 1-7, 2012.

[7] L. E. Armstrong, E. C. Johnson, and M. F. Bergeron, "COUNTERVIEW: Is Drinking to Thirst Adequate to Appropriately Maintain Hydration Status during Prolonged Endurance Exercise? No," Wilderness Environ. Med., vol. 27, no. 2, pp. 195-198, 2016.

[8] D. L. Costill and W. Fink, "Muscle water and electrolytes following varied levels of dehydration in man," vol. 40, no. 1, 2018.

[9] A. Klein et al., "Hydration biomarkers in free-living adults with different levels of habitual fluid consumption," pp. 1678-1687, 2013.

[10] S. N. Thornton, "Physiology \& Behavior Thirst and hydration: Physiology and consequences of dysfunction," Physiol. Behav., vol. 100, no. 1, pp. 15-21, 2010.

[11] D. C. Garrett et al., "Engineering Approaches to Assessing Hydration Status," vol. 3333, no. c, 2018.

[12] B. D. Altinsoy, O. B. Ozakpinar, B. Gurbuz, P. Rayaman, I. Ocsoy, and U. S. Gurer, "Green synthesis and characterization of silver nanoparticles using the fungus a. Niger and bioactive potential against microorganisms and cancer cells," Lat. Am. J. Pharm., vol. 37, no. 5, pp. 979-986, 2018.

[13] C. J. Hall and A. M. Lane, "Effects of rapid weight loss on mood and performance among amateur boxers," Br. J. Sports Med., vol. 35, no. 6, pp. 390-395, 2001.

[14] "Design and Implementation of Microcontroller Based Calculator," $J$. Comput. Biosci. Eng., vol. 1, no. 2, pp. 31-35, 2014.

[15] T. Miyake et al., "Low urine $\mathrm{pH}$ is associated with non-alcoholic fatty liver disease: A community-based cross-sectional study," Intern. Med., 
vol. 57, no. 19, pp. 2799-2805, 2018.

[16] E. M. Worcester, K. J. Bergsland, D. L. Gillen, and F. L. Coe, "Mechanism for higher urine $\mathrm{pH}$ in normal women compared with men," Am. J. Physiol. - Ren. Physiol., vol. 314, no. 4, pp. F623-F629, 2018.

[17] R. Z. Amani, R. Maulana, and D. Syauqy, "Sistem Pendeteksi Dehidrasi Berdasarkan Warna dan Kadar Amonia pada Urin Berbasis Sensor TCS3200 Dan MQ135 dengan Metode Naive Bayes," vol. 1, no. 5, pp. 436-444, 2017.

[18] A. A. S. Gunawan, D. Brandon, V. D. Puspa, and B. Wiweko, "Development of Urine Hydration System Based on Urine Color and Support Vector Machine," Procedia Comput. Sci., vol. 135, pp. 481489, 2018.

[19] K. Samu and B. Thamó, "Internet based light quality measurement," Recent Innov. Mechatronics, vol. 4, no. 1, pp. 4-8, 2017.

[20] Texas Advanced Optoelectronic Solutions Inc., "COLOR LIGHT-TODIGITAL CONVERTER with IR FILTER End Products and Market Segments Texas Advanced Optoelectronic Solutions Inc . COLOR LIGHT-TO-DIGITAL CONVERTER with IR FILTER," datasheet, no. 972, p. 2, 2012. 